Paper accepted for publication (the version below is the final version prior to proof). The paper was eventually published in Asia Pacific Business Review, 2015, Vol. 21, no. 1, January, pp. 147-53, DOI: 10.1080/13602381.2014.939900.

\title{
Transformation of China's Energy Sector: Trends and Challenges
}

\section{Hongyi Lai*,}

Faculty of Social Sciences,

University of Nottingham,

Nottingham,

NG8 1BB

and

Malcolm Warner,

Judge Business School,

University of Cambridge,

Cambridge,

CB2 1AG

*EMAIL: Hongyi.Lai@nottingham.ac.uk

\begin{abstract}
The conclusions presented here sum up the contributions in the Special Issue regarding the managing of China's energy sector, particularly regarding the demand and profile of energy as well as the marketization of the sector. Strategic, organizational and policy issues relevant to the main theme are set out. Both demand and supply scenarios for the nation's energy are seen as in flux, as the economy slackens and dependence on imports rises. Unprecedented levels of urban environmental pollution and steady growth of energy consumption in the wake of a rising living standard have
\end{abstract}


brought the issue to headline-prominence as never before. China's rapidly increasing renewable energy will not change its heavy reliance on coal and a lesser extent oil in the coming decade.

After decades of transformation, China's energy sector now operates in a domestic market characterised by strong governmental influence and monopolistic state firms. Abroad, China's firms are exposed to heavier market pressure and competition. Whilst the state's policies have succeeded in ensuring energy supplies and propelling China's renewable energy manufacturers into global prominence and opening up domestic market, much room for improvement exists in the competitiveness of the domestic market and domestic energy firms, transparency of pricing, and the effectiveness of regulation.

\section{Keywords}

Asia, China, economics, energy, environment, pollution.

\section{Introduction}

In this concluding contribution, we will try to present an overview of the main upshot of this Special Issue.

As the World Bank (2014:1) has noted: 'China's 12th Five-Year Plan (2011-2015) ... highlights the development of services and measures to address environmental and social imbalances, setting targets to reduce pollution, to increase energy efficiency, to improve access to education and healthcare, and to expand social protection. Its annual growth target of 7 percent signals the intention to focus on quality of life, rather than pace of growth'.

With the news that China will pass a new environmental law, it is clear that pressure of public opinion has had its effect on the Chinese legislature to deal with the above issues. According to Xinhua - 'Senior Chinese lawmakers on Wednesday expressed concerns over the country's low energy efficiency and high emissions, as a recent report suggested that China is lagging behind its energy conservation and emission reduction targets' (Xinhua 2014:1). China has set tight targets for emission cuts and energy saving in its 12th Five-Year Plan (2011-2015), by which consumption of energy per unit of GDP should be cut by 16 percent and carbon dioxide emissions should fall by 17 percent by 2015 from the levels of 2010.

China's recent economic slowdown has also focussed attention of the demand and supply for energy. But the percentage of imports in China's energy-mix is rising. Among its worries are the strategic ones relating to movement of oil-tankers which come from the Gulf as they pass through the Malacca Straits. There is even talk of building an access-port on the Burmese coast and moving oil by pipeline straight to the Chinese mainland. Its imports of oil projected to surpass those of the US as the world's largest importer by 2015 and to become its largest oil consumer, say, by 2030 .

On the demand side, the utilization of energy has slackened. Economists have long looked at energy consumption as a proxy for economic growth and no less in the Chinese case (see Rawski 2001: 347). 
A falling rate of growth may mean less energy is consumed if the official statistics can be trusted (see Sinton 2001:373). Domestic coal demand is down and prices have fallen. On the supply side, it is clear that national resources are under constraint - China already produces almost a quarter of the world's coal - but domestic supplies are feeling the brunt. China's coal-boom is coming to an end as high labour costs add to its woes. The government is threatening to close high-cost coal-fired power stations. Nevertheless, this slowdown in energy demand may be a development in the short or intermediate term. In the long run, as urbanization is almost sure to progress and the people's living standard to increase, energy consumption may well be on the upward trend.

However, China has allegedly embarked on a 'green revolution'; it has abundant alternative energy resources: 'China has abundant clean energy resources. Hydroelectricity has the potential of 600 million kilowatts, wind and solar power generation can reach 2.5 billion kilowatts and 2.7 billion kilowatts respectively. If all these resources can be converted into electricity effectively, $50 \%$ of China's energy consumption can come from non-fossil fuel sources' (see Wall Street Journal 2014:1).

On the other hand, talk of a 'green revolution' may not only be glib, but even premature given the extent of China's energy dilemmas. China is now estimated to be the world's top emitter of greenhouse gases, having overtaken the US in 2007. The degree of pollution in Beijing is already almost unprecedented by WHO standards. In late Winter 2014, the concentration of PM 2.5 particles - those which go deep into the lungs and into the bloodstream - rose to 505 micrograms per cubic metre, where the international agency recommends a safe level of around 25 . Scientists talk of it resembling a 'nuclear winter'. According to a 2012 Asian Development Bank report, less than 1 percent of China's 500 biggest cities would satisfy the WHO's air quality standards. The possible effects on health and life expectations are dire. Environmental damage, in total, may be costing up to ten percent of the nation's growth annually. Yet a pro-active reduction of GDP expansion is not really on the agenda.

In light of the severity and colossal implications of energy in China, it is imperative that a rigorous and timely understanding of this topic be generated. This Special Issue has delivered a robust attempt to address issues related to this topic. These topics include the current and projected conditions of energy demand and energy mix, the role of and governmental policies toward renewable energy, the reform, regulation, and corporate governance of gigantic state energy firms, the internationalization of the largest state oil and gas firms, and the rise and transformation of the solar PV industry and market.

\section{Findings}

The main themes of the contributions* to this Special Issue can be listed as follows (see Table 1). 
Table 1. The main themes of the contributions

- Development and diversification of energy profile STRATEGIC

- Development and pattern of China's renewable energy STRATEGIC

- Reform of national state-owned energy enterprises (SOEs) and SOEs-state relations ORGANIZATIONAL

- Reform and corporate governance of SOEs GOVERNANCE

- Pattern and rationale of overseas investment of China's major energy firms ECONOMIC

- State subsidies and domestic and international markets of China's Solar PV industry POLICY

- Global networks and expansion of China's solar PV industry ORGANIZATIONAL

- Spatial differentiation of per capita embedded carbon footprint (ECF) in urban China and key determinants GEOGRAPHICAL

\section{INSERT TABLE 1 ABOUT HERE}

The common threads linking the above contributions to this Symposium are three fold. The first is the economic importance of energy in general and of coal as an energy source, as well as the phenomenal rise of renewable energy. The second is the international significance of China's energy firms, especially those related to oil and gas and solar PV manufacturers. The third is the 
omnipresent influence of the state in the transformation of the conventional and renewable energy sectors in China.

The distinctive threads differentiating the contributions to this Special Issue may be found to relate to Thomson and Boey (2015), Lai, Ohara and Wysoczanska (2015), Gress (2015), and Fan, Wu, Guo, Zhao and Marinova (Wu et al 2015). Thomson and Boey (2015) suggest that China's energy consumption will continue to grow, and while China's dependence on coal, and to a lesser extent oil, will continue, the contribution from nuclear, gas, and renewable energy will rise. They also suggest a growing role for nuclear and gas energy. Lai et al. (2015) highlight the growing international investment profile of Sinopec and CNPC and the relative prominence of strategic assets and sectoral specialisation in the overseas deals of both giants. Gress (2015) uncovers the importance of commercial and cultural factors in the Chinese solar PV firms. He finds that firms place critical importance on product, price, and competency when choosing suppliers and buyers, somewhat typical of high tech firms, but that there is none the less a lingering influence of culture, location and personal relationships on these decisions, particularly for firms less firmly ensconced in global networks. Wu et al (2015) devote their attention to the factors underlying embedded carbon footprint (ECF) across provinces in China. They find that the coastal provinces have the highest per capita ECF and that per capita disposable income determines the per capita ECF. They also find that a higher level of per capita income in a province is associated with lower consumption and ECF of food, housing, as well as health, education, and recreation, but a higher level of transport and related ECF.

Many of these deal with a range of policy issues related to energy and the energy business. Thomson and Boey (2015) caution against the excessive optimism over renewable energy in China and point to the continuous dominance of coal as an energy source in the coming decades. They do see greater room for policies promoting diversification of energy sources, such as nuclear, gas, wind and solar power. Dent (2015) gives credit to the state-directed expansion of renewable energy in China. He sees the state's policy of mixing regulatory mandates, financial support and market-based tools as a key to China's rapid rise as the leader in renewable energy generation capacity in the world. Through public investment and state energy firms, the state acts as a supplier of public goods in jump-starting the growth of renewable energy and making them gradually commercially viable. The only exception to public investment is in the solar PV industry, which has remained largely private. Seconding Dent's thesis is Chen's (2015) argument that the state's subsidies have helped the solar PV and wind power manufacturers in China to conquer the global market at the early stage of their development. Chen (2015) also argues that at a later stage the state's subsidies are helping the solar PV and wind turbine manufacturers to expand the still premature domestic market and reduce their reliance on the saturated international market. The reform of state energy firms also relates closely to policies. Liao (2015) argues that the Chinese government has only embraced halfhearted restructuring and allows colossal state energy firms to continue to exercise a massive influence on price setting and the disposal of their profits. Rooker (2015) sheds light on the limits of reform of state energy firms and deficiency of corporate governance, which is reflected in the absence of growth in market-based financing for these firms. 


\section{Discussion}

Our aforementioned findings can be summarised as two "betweens"-- between conventional and renewable energy and between the market and the state. There are three main points to make here. The first following point relates to the first between, whereas the second and third following points concern the second between.

First, a range of energy sources will co-exist and expand in China. These sources include coal and oil, renewable energy - chiefly hydro, wind, and solar power, as well as cleaner or advanced conventional energy such as gas and nuclear. While China will continue to expand and reply on coal and oil, the country will expand its use of nuclear and gas power, which has thus far been severely underutilised. In May 2014 Russian state-controlled entities Gazprom and China National Petroleum Corp (CNPC) signed a \$400-billion and 30-year gas supply deal in Shanghai. Under this biggest ever energy contract it has ever signed Russia will begin delivering gas from 2018, gradually increasing to 38 billion cubic metres a year and totalling over 1 trillion cubic metres for a whole contractual period (BBC 2014). More importantly, renewable energy in China will grow even much faster than coal and oil, consolidating China's status as the leader in power-generation capacity of renewable energy. We will thus expect to see explosive expansion of China's firms specialized in renewable energy especially wind and solar, and to a lesser extent, hydro. Also, a surge in use of energy sources such as nuclear and gas is likely. We should also expect steady growth of firms specialised in conventional energy such as coal and oil.

Second, the state has been and will remain a major player in the development and transformation of the energy sector in China. As Dent (2015), Chen (2015), and Gress (2015) document, the state plays an instrumental role in strategically grooming the infant industry of solar PV and wind power manufacturers in the international market and then in the domestic Chinese market. No wonder in a survey conducted by Gress (2015) solar PV firms in China attached high importance to their ties with national and local governments. On the downside, the state is reluctant to decisively turn the largest energy firms into truly market-based corporate players. It allows them to enjoy near monopoly positions in their own sectors, wield strong leverage on energy policies, and enjoy and use internal financing as a way to escape the disciplining of market-based financing.

Third, the market exercises its influence directly in sectors with pervasive global linkages (such as the solar PV manufacturing and state firms listed in the international market), but less so in sectors which have less international exposure (such as coal and oil production and electricity generation). Gress (2015), for example, finds that Chinese solar PV firms are highly cognizant of the importance of both national and local governments abroad to their business success, and that they engage international trade shows to build corporate and brand recognition globally. Interestingly, he also finds that enrolling in global networks impacts the depth and breadth of Chinese solar PV firm supplier and buyer networks abroad. In addition, Rooker (2015) finds that major Chinese oil and petrochemical firms (especially firms other than CNPC and Sinopec) have relied more on related 
party transactions and internal financing, and that they have resorted less to market-based financing which imply corporate oversights and market disciplines. When dealing with international corporate players and in making overseas investment, Lai et al. (2015) find that market-based factors such as sectoral specialization and strategic assets have been granted prominent consideration.

\section{Conclusions}

Our conclusions point to the strides and limits in transformation of the energy sector in China. As highlighted above, the state has successfully overseen and funded the rise of renewable energy firms as global players of manufactures. It has also allowed the largely oil and gas firms to expand aggressively around the world. Yet there is much to desire for in terms of marketisation of state energy firms especially inside China and of the transparency of energy policies. Viewed in this light, the transformation of the energy sector in China is incomplete, stuck between the state and the market. Limits are apparent in areas concerning institutions and regulations, such as corporate governance, corporate financing, and competitive pricing to the advantage of consumers.

Nevertheless, the Chinese policymakers might have seen the situation very differently-they have come to abhor the free market whose vice has been shown in its ugly full form via the economic rampage caused by the financial crisis in 2008. They may accept the hybrid of a state-directed market as a 'virtuous model' for economic and corporate development in China.

Turning to the issue of energy mixture, the continuous prominence of energy sources such as coal and oil in China can have dire implications for the world. Combustion of per unit of coal and oil generates far higher carbon emission than other energy sources such as gas and renewable energy sources. Furthermore, as Wu et al. (2015) suggest, per capita embedded carbon footprint will inevitably grow when per capita disposable income rises across provinces in China. China is certainly heading toward this direction with continuous, albeit slowing, economic growth. The Chinese may also view increasing energy consumption as their natural right similar to that enjoyed by residents in developed economies. This downside of expanding energy demand is mitigated partially by the explosive growth of renewable energy in China.

As The Economist (20131) has put it: 'Yet China also has advantages in addressing its - and the world's-environmental problems. Its leaders understand the challenge of climate change better than their predecessors and perhaps their international peers, too. They are good at taking action on high-priority issues. Because the country is a late developer, it should be able to learn from the mistakes of others-and not build energy-guzzling cities. China has a huge domestic market, cheap capital and sunny, windy deserts: the ideal environment to build a zero-carbon energy system. It is the silver lining of a very dark cloud. If China cannot do it, no one can.' 


\section{Bio-data}

HONGYI LAI is Associate Professor at the School of Contemporary Chinese Studies, University of Nottingham, UK. His research and multiple journal articles cover China's national and local reform strategies, regional development in China, as well as China's oil diplomacy and the internationalisation of its energy firms. His books relate to China's political economy include Asian Energy Security: The Maritime Dimension (London: Palgrave-MacMillan, 2009) and Reform and the Non-State Economy in China (London: Palgrave-MacMillan, 2006).

MALCOLM WARNER is Professor and Fellow Emeritus, Wolfson College, Cambridge and Judge Business School, University of Cambridge. He has been the Editor-in-Chief, of the International Encyclopedia of Business and Management [IEBM], 8 volumes, (London: Thomson, 2002) and the author/editor of many books and articles on China. His latest work has recently been published: Understanding management in China: Past, present and future, (London and New York, NY: Routledge, 2014). He is currently Co-Editor of the Asia Pacific Business Review.

\section{References.}

(All contributions to the Special Issue mentioned above are not specifically noted in the references below, the reader is asked to refer to the Contents for these).

BBC, 2014. "Russia Signs 30-year Gas Deal with China," posted at http://www.bbc.co.uk/news/business-27503017 [accessed 21 May 2014].

Chen, G. 2015. "From Mercantile Strategy to Domestic Demand Stimulation: Changes in China's Solar PV Subsidies," Asia-Pacific Business Review, issue and page number to be inserted.

Dent, C. 2015. "China's Renewable Energy Development: Policy, Industry and Business Perspectives," Asia-Pacific Business Review, issue and page number to be inserted.

Economist, The (2013) 'China and the Environment: The East is Grey', The Economist, 10 August 2013: 1, http://www.economist.com/news/briefing/21583245-china-worlds-worst-polluter-largestinvestor-green-energy-its-rise-will-have [accessed 1 May 2014].

Fan, J., Wu, Y., Guo, X., Zhao, D. and Marinova, D. 2015. "Regional Disparity of Embedded Carbon Footprint and Its Sources in China: A Consumption Perspective," Asia-Pacific Business Review, issue and page number to be inserted.

Gress, D., 2015. "Enrolling in Global Networks and Contingencies for China's Solar PV Industry," Asia-Pacific Business Review, issue and page number to be inserted. 
Lai, H., O'Hara, S., and Wysoczanska, K. 2015. "Rationale of internationalisation of China's NOCs: Natural or Strategic Resources Seeking?" Asia-Pacific Business Review, issue and page number to be inserted.

Liao, J. X. 2015. "The Relationship between the Chinese Government and the National Oil Companies (NOCs): Who Is the Principal?" Asia-Pacific Business Review, issue and page number to be inserted.

Rooker, T. 2015. "Corporate Governance or Governance by Corporates? Testing Governmentality in the Context of China's National Oil and Petrochemical Business Groups," Asia-Pacific Business Review, issue and page number to be inserted.

Rawski, T. G (2001) 'What's Happening to China's GDP Statistics?' China Economic Review, 12.4, December, 347-354.

Sinton, J. E (2001) 'Accuracy and reliability of China's energy statistics',

China Economic Review, 2001, vol. 12, 4, 373-383 Thomson, E. and Boey, A. 2015. "The Role of Oil and Gas in China's Energy Strategy: An Overview," Asia-Pacific Business Review, issue and page number to be inserted.

Wall Street Journal (2014) The Smart Way to Power China, Wall Street Journal, 24 April 2014:1, http://online.wsj.com/news/articles/SB10001424052702304518704579521082841768734 (accessed 27 April 2014).

World Bank (2014) 'Overview', Washington, DC: World Bank, 1 April 2014: 1, http://www.worldbank.org/en/country/china/overview, (accessed 1 May 2014).

Xinhua (2014), 'Report, Chinese lawmakers worried over energy efficiency and emissions', http://news.xinhuanet.com/english/china/2014-04/23/c_126426250.htm (accessed 25 April 2014).

END 